\title{
Availability Bias Can Improve Women's Propensity to Negotiate
}

\author{
Yellowlees Douglas ${ }^{1} \&$ Samantha Miller ${ }^{2}$ \\ ${ }^{1}$ Hough Graduate School of Business, Warrington College of Business Administration, University of Florida, \\ Gainesville, FL, USA \\ ${ }^{2}$ Heavener School of Business, Warrington College of Business Administration, University of Florida, Gainesville, FL, \\ USA
}

Correspondence: Yellowlees Douglas, Ph.D., Hough Graduate School of Business, Warrington College of Business Administration, PO Box 117150, University of Florida, Gainesville, FL 32611-7150, USA. Tel: 1-352-273-3215. E-mail: jane.douglas@warrington.ufl.edu

Received: February 19, 2015

Accepted: March 3, 2015

Online Published: March 5, 2015

doi:10.5430/ijba.v6n2p86

URL: http://dx.doi.org/10.5430/ijba.v6n2p86

\begin{abstract}
Women's reluctance to negotiate aggressively on their own behalf has long been thought to account for the striking disparities between the salaries earned by men versus women. Extensive research has documented women occupying a low-wage "sticky floor," encountering mid-level career bottlenecks, or being confined by a glass ceiling. In numerous studies, women have undervalued themselves, responded to stereotypes on women's lack of aggressiveness, or placed greater value on interpersonal relationships even in negotiating salaries. However, this study found that, contrary to most studies on women's and men's propensity to negotiate, women negotiated as aggressively as did their male colleagues. Not only did more women than men negotiate aggressively for a reward, but women relied on heuristics usually seen as misleading in decision-making to make demands in their favor. This study focuses on women's and men's reliance on availability, anchoring, and framing - staples of understanding negotiating behavior independent of sex-in requesting rewards, linked notably to perceptions of the value of their highest-earned salaries and to their job performance compared to their workplace colleagues'. When faced with situational ambiguity and an absence of targets in negotiating a first offer or reward, women may improve their negotiating skills through training that uses priming, availability, or counterfactual thinking.
\end{abstract}

Keywords: women and negotiation, availability bias, framing, priming, anchoring, heuristics

\section{Introduction}

\subsection{Women Underperform in Negotiation}

Women and their performance in negotiation has long been a conundrum-puzzled over by researchers, amply attested to in both simulations and longitudinal studies. For decades, studies have attested to different attitudes and behaviors that distinguish the way men and women handle negotiation. In addition, the implications for women negotiating salaries - particularly an initial negotiation of starting salaries - is profound. In the initial negotiation of starting salaries, men negotiate more aggressively to increase their original offers, bolstering their salaries. Even for players in what should be a level playing field - graduates of an Ivy League MBA program - men negotiated starting salaries that were $4.3 \%$ higher on average than the salary their new employers offered them. In contrast, women negotiated increases that averaged only $2.7 \%$ higher than their first averages (Gerhart \& Rynes, 1991). For that single negotiation, male employees enjoy a payoff that is $59 \%$ higher than the amount earned by female employees. If men at every stage of their careers negotiate raises more aggressively than women, by the time they retire male employees make nearly double the salaries earned by female employees (Babcock \& Laschever, 2003).

As Gerhart and Rynes (1991) found more than two decades ago, even credentials fail to make significant impacts on women's propensity to negotiate less aggressively than men. In addition, women still negotiate, on average, starting salaries 30\% lower than their male colleagues', demonstrated in a study of MBA students schooled in negotiation and at competitive Ivy League programs that should have produced some of the most capable and tough-minded female negotiators in the workplace (Riley, Babcock \& McGinn, 2003). Apparently, schooling and training in negotiation fail to compensate for the dramatic differences in negotiation tactics used by men and women. 
Ultimately, researchers agree on one point concerning women and negotiation: the "accumulation of disadvantage" (Babcock \& Laschever, 2003). Furthermore, researchers have attributed to differences in performance and outcomes in negotiation between men and women everything from corporate glass ceilings (Tesch, Wood, Helwig \& Nattinger, 1995; Yap \& Konrad, 2009) and underpaying sticky floors (Kee, 2006; Rainbird, 2007) to "slow elevators" to top positions in their chosen fields (Greig, 2008).

\subsection{Why Do Women Negotiate Less Aggressively than Men?}

To date, the literature on women and negotiation has focused on a range of social and cognitive biases. Both men and women alike undervalue women compared to men (Albeida \& Tilly, 1997; Stuhlmacher and Walters, 1999; Trout, 2005), while women value interpersonal relationships over compensation (Kray \& Thompson, 2005; Kray \& Babcock, 2006). Women also set lower initial targets in making first offers than men (Kray \& Gelfand, 2009), potentially due to risk aversion (Rosette, Kopelman \& Abbott, 2014). In addition, women's social networks have fewer career mentors in them (Babcock \& Laschever, 2007) and also fewer casual ties that can benefit women in securing job offers and promotions (Granovetter, 1983).

However, evidence increasingly points to the utility of cognitive explanations that include some of the same heuristics that impact negotiations both inside and outside the workplace. In particular, heuristics that play significant roles in behavioral economics - anchoring, priming, and availability — play significant roles in self-perception and performance (Aronson \& Steele, 1995; Shih, Pittinsky \& Ambady, 1999) and, specifically, in negotiation itself (Magee, Galinsky \& Gruenfeld, 2007; Haselhuhn \& Kray, 2011). Although Fiona Greig's 2008 study focused on behavioral constraints on women in negotiation, her study provided compelling data, partly based on her manner of measuring participants' propensity to negotiate via a seemingly casual invitation to participants to identify the amount they wanted on a rewards card as compensation for completing her questionnaire. Greig's participants included employees at a major investment bank, where women would have a greater propensity to negotiate than employees at other organizations or in other fields. In addition, her questionnaire elicited feedback on promotion, enabling her study to identify correlations between the amounts employees requested on their rewards card and the speed with which they received promotions. On average, employees who showed lower propensity to negotiate earned promotions seventeen months later than employees who negotiated more aggressively-even for a simple rewards card (Greig, 2008).

\subsection{Hypothesis: Women Will Negotiate Less Aggressively than Men in Responding to a Seemingly Innocuous Request} for Rewards

We hypothesized that students enrolled in a competitive MBA program, with work experience in a range of fields and less disposable income than bankers and traders, would behave similarly to Greig's participants. However, we expected men to display more aggressive negotiating behavior because they had less disposable income than Greig's populations. We also anticipated that these economic factors would lead to a greater disparity between the more aggressive and mostly male requests for rewards and the amounts requested by female participants.

\section{Existing Explanations for Why Women Negotiate Less Aggressively than Men}

A variety of factors may account for differences between the way men and women negotiate, including social perceptions of value, stereotyping, differing attitudes toward interpersonal relationships, and social networks that provide valuable cues for establishing target values. Certainly, wider social perceptions weight women as less adroit at negotiation than men. In studies of car dealerships, Ayres and Siegelman (1995) found women and minority car buyers paid significantly more for cars, following initial offers and negotiations by Chicago car salesman, than did white male buyers. However, when female and minority buyers negotiated automobile purchases online, where their sex and race were masked, buyers paid nearly the same prices as those paid by white males (Morton, Zettelmeyer \& Silva-Risso, 2003). Apparently, sex is a potent cue of an individual's willingness to negotiate aggressively, a finding supported by Solnick's 2001 study of negotiation between two pairs who never met one another. Told only the sex of the other negotiator, men and women nevertheless both made less generous offers when they believed they were negotiating with a woman, rather than a man — averaging 12\% lower than offers given to men (Solnick, 2001).

Women may also link negotiation to self-perceptions of their efficacy, particularly in supervisory or managerial roles. Even in a simulated organization, men designated "supervisors" reported scores of their managerial ability $31 \%$ higher than those reported by women participants (Instone, Major \& Bunker, 1983). Women even expect to earn less on the job than men do, as much as $15 \%$ less in their first year on the job and over $45 \%$ less than men in their peak-earning year (Major \& Konar, 1984). In the same study, Major and Konar (1984) found that women expected others working the same jobs as them to make less than men did of the same position. Tellingly, women paid 
themselves considerably less for a fixed amount of work than men did — but only when comparison information they might gain from colleagues was absent. When women had access to comparables for pay, both men and women paid themselves similar amounts (Major, McFarlin \& Gagnon, 1984).

\subsection{The Role of Social Networks and Cues in Negotiation}

Women may negotiate more poorly because they are deprived of access to anchors to suggest a salary, first offer, or consulting fees. Notably, women form networks with other women, while men network socially and in the workplace with other men. Men benefit from access to their networks, as men typically control decisions on promotions and on salaries (Babcock \& Laschever, 2007). In addition, men's social networks form the weak ties that provide men with access to promotions, salary targets, and consulting fees (Granovetter, 1973). However, these same counter-intuitively powerful weak ties that help men negotiate higher salaries and fees fail to benefit women, as women's weak ties bind them to colleagues with the same lack of access to salary targets and promotions (Granovetter, 1983). The absence of social comparatives on salaries also plays a role in women negotiating lower first offers than men, increasing women's anxiety at getting their first offer rejected, exacerbated by women's lower feelings of self-worth compared to male colleagues or job candidates (Rosette, Kopelman \& Abbott, 2014).

\subsection{Behavioral Explanations for Disparities between Sexes in Negotiation}

Researchers have already employed behavioral explanations to explore differences between the sexes in negotiation, including stereotyping (Stuhlmacher \& Walters, 1999; Bowles, Babcock \& McGinn, 2005), framing (Tversky \& Kahneman, 1981) and priming (Magee, Galinsky \& Gruenfeld, 2007). In particular, heuristics, used heavily in behavioral economics, plays an interesting role in potentially explaining the disparity between women's and men's efficacy in negotiation via anchoring (Rosette, Kopelman \& Abbott, 2014), the halo effect (Kahneman, 2011) and similarity (Burger, Messian, Patel, del Prado \& Anderson, 2004). In particular, similarity heuristics explain the "sticky floor," where women's loose ties and reliance on similarity biases prompt low-level supervisors to hire other women for low-paying jobs, at the same time similarity prompts men to hire other men for higher-level positions (Kee, 2006; Rainbird, 2007; Shambaugh, 2007).

Similarity, anchoring and the halo effects likely play a central role in men's skill in negotiation. However, we understand less clearly the role played by behavioral heuristics in women's performance in negotiation. Here we encounter an unanticipated outcome on women's negotiating behaviors best explained by availability biases, which have hitherto played few explicit roles in explanations of women's negotiating behavior but which may play a vital role in enabling women to negotiate higher salaries.

\section{Methods}

\subsection{Women Traditionally Low-ball Negotiation Requests}

Much of the literature on women and negotiation has focused on social attitudes toward women's reluctance to negotiate salaries as aggressively as their male counterparts. Studies have used simulated negotiations with Prisoner's Dilemma-type scenarios (Stuhlmacher \& Walters, 1999; Wheeler \& Petty, 2001; Bowles, Babcock \& McGinn, 2005), negotiation scenarios (Magee, Galinsky \& Gruenfeld, 2007; Kray, Kennedy \& Van Sant, 2014), and behavioral negotiation tasks (Kray \& Haselhuhn, 2007; Kray, Galinsky \& Markman, 2009). However, these simulated scenarios may skew participants' responses, especially given the constructs typically used in studies conducted within the confines of academic programs, the case with the majority of the interactional studies (Bowles, Babcock \& McGinn, 2005; Kray, Galinsky \& Wong, 2006; Kray, Galinsky \& Markman, 2009, Rosette, Kopelman \& Abbott 2014). Scenarios and simulations within an academic environment may measure baseline propensities of men and women in handling negotiation, but if participants have an opportunity to negotiate a measurable reward which they will receive, their behavior may provide a more accurate reflection of their negotiating strategies. As a result, we followed Greig's 2008 experimental design, since her study relied on a survey created to elicit and capture behavioral responses in the throes of an actual negotiation. In her survey, Greig (2008) used a then-novel approach to assessing propensity to negotiate by closing her survey with a casual question, similar to one used in many online measures of consumer satisfaction, informing participants that they could receive a Starbucks card as a reward for answering the survey. However, Greig deliberately avoided providing any anchors for the amount participants could request, leaving the response open-ended, theoretically enabling participants to request nothing or as much as $\$ 100$ (Greig 2008).

\subsection{Experimental Assumptions}

Consistent with Babcock and Laschever (2003), Greig anticipated women would be more reluctant to negotiate, in addition to requesting lower amounts than men surveyed (Gerhart and Rynes 1991; Greig 2008) and would also rely 
on self-evaluations of their self-worth anchored by performance evaluations within the preceding twelve months (Greig 2008). Given the characteristics of students enrolled in the University of Florida's one- and two-year MBA programs, we had a pool of participants with diverse but mostly extensive work experience, largely in fields where quantitative skills were de rigueur, thus providing us with a snapshot of women working in traditionally male-dominated fields from biomedical engineering to financial analysis. Given the selectivity of the on-campus MBA cohorts at Florida, these candidates, both male and female, were typically high achievers and had left careers where they earned substantial salaries to return to academia, either to change fields or to bolster their earnings potential still further.

\subsection{Framing of the Hypothesis}

We hypothesized, consistent with Greig (2008), that women would request substantially lower sums on their Starbucks cards. We also hypothesized that these requests might reflect influences from other workplace experiences. These influences including prior success in negotiations (Kray \& Haselhuhn, 2007) and receiving high scores on performance evaluations within the preceding twelve months (Greig, 2008). We also anticipated value requests might reflect influence based on self-perceptions about risk aversion or risk-seeking behavior at work, reflecting women's anxiety in making an initial first offer when requesting a salary (Kray \& Gelfand, 2009; Rosette, Kopelman $\&$ Abbott, 2014). Consistent with our survey eliciting information about participants' prior work experience, we also solicited information on the highest salaries they had earned to date. We anticipated that our survey would find correlations between self-perceptions about negotiating skill and participants' salaries, which would be consistent with either a negotiating strategy more like approaches used by men or a lack of inhibition in setting a high initial target amount in an initial salary request, both of which would generate higher salaries for women. However, we expected that self-perceptions of skill in negotiation and in taking risks, as well as self-reported efficacy in prior negotiations would be more closely correlated with the amount requested for the Starbucks reward card, rather than participants' salaries. We anticipated that the cross-section of organizations and fields in which our participants had work experience could skew correlations between salary and requested amounts, as some of our MBA students had as many as fifteen years' more work experience than their younger counterparts.

\subsection{Experimental Design}

The primary research instrument was a short 16-question survey conducted with a sample of 25 (10 female and 15 male) students enrolled in the 2 year MBA program at the University of Florida. The participants were sent a link via email to complete an online questionnaire. The email contained a short introduction from a widely-known professor, with whom $80 \%$ of the sample have taken at least one course with. The participants were informed that the questionnaire results were completely anonymous and contained no questions with unique identifiers. We designed the survey to include sham questions about novelty and risk aversion to avoid biasing answers and outcomes.

\subsection{Survey Design}

Information about demographic, perception, and constraint-related variables were collected as follows:

1. Demographics: Questions 1, 2, 3, 4, 5 and 7, asked for the respondent's age, sex, race, and nationality, highest level of education completed, and marital status, respectively.

2. Work experience: Questions 6, 8, 9, 10, and 12 asked the respondent to answer questions about his/her work experience (i.e. current title and company employed by, highest salary received, is he/she currently receiving that salary, and last two performance review numbers).

3. Workplace constraints: Question 11 asked the respondent to list any workplace constraints he/she has experienced.

4. Self-confidence and self-perception: A 5-point Likert scale was used for questions 15-19 asking the respondent to state the level with which he/she agrees or disagrees with the statements listed below $(1=$ strongly disagree, $5=$ strongly agree).

a. I feel I perform better than my co-workers in similar job positions in terms of work performance last year.

b. I spend too much time at work.

c. I am an average negotiator.

d. I avoid risk whenever possible.

e. I am very open to novelty.

In addition, questions 13 and 14 asked the respondent to answer the following open-ended questions: 
f. What prior experience have you had negotiating over the past 12 months?

g. Do you feel you have taken significant risk in the past 12 months?

\subsection{Coding}

All responses were given a numerical code, corresponding to established divisions (i.e., coding male as 1 and female as 2). We were unable to code for previous negotiating experience, due to highly varied results ranging from no experience to experience negotiating tax penalties with the IRS. We were also unable to code for responses related to last two performance review numbers due to the majority omitting an answer, claiming they did not know the number, or that they have not received a performance review. Similarly, we were unable to code for experience taking significant risks, with results ranging from no experience taking risk to reporting taking risk by riding a motorcycle without a helmet.

In this study, propensity to negotiate for oneself is observed as the tendency to initiate an interaction with the intention of improving the rewards for the duties performed (Greig, 2008). Propensity to negotiate was measured using a behavioral method: at the end of the questionnaire, participants were told they could receive a Starbucks card using the phrasing, "In appreciation for your participation, you will receive a free Starbucks card. However, the value of this Starbucks card has not yet been determined. How much do you request your Starbucks card to be for?" to replicate Greig's study closely (Greig, 2008). A Starbucks card was offered because the University of Florida campus has three Starbucks locations on the campus itself, and several more located within two miles of the campus. The final question was designed to be open-ended and provide no anchors or format restrictions that could influence the participants' requests. As such, each participant had identical opportunity to negotiate for a monetary reward. Following Greig's study, propensity to negotiate was assessed by coding participants' responses requesting any monetary amount from $\$ 0$ to $\$ 25$ as 2 for "Made Request" and requests of $\$ 0$ as 1 for "Made Request of $\$ 0$." Responses such as "I don't drink coffee" and "N/A" were coded as 0 for "Made No Request."

\section{Results}

\subsection{Participant Demographics}

The sample consists of 25 subjects with ages ranging from 22 to 40 . The average age was 26.92 , which is roughly 9 years younger than the reported average age of respondents in Greig's study. The survey was sent to 108 MBA candidates across a 1-year MBA program and a 2-year MBA program. Of the 108 in the program, 32 are women, making up $29.63 \%$ of the program. Men make up $70.37 \%$ of the program with 76 students. Of the 25 students who responded (23.15\% response rate of the 108 in the programs), 10 were women and 15 were men. The survey respondents accurately reflected the proportion of women in the MBA programs' student enrollment, with $31.25 \%$ of the respondents being female. Men, on the other hand, were underrepresented, with only $19.74 \%$ responding of the 76 in the program.

\subsection{Reward Values Requested}

The average value requested by those who made a request is $\$ 7.58$. The average values requested by women were $\$ 9.70$, contrasting with men's requests for an average of $\$ 4.65$, with women asking for approximately $\$ 5$ more than men. This outcome is different from that of Greig's 2008 study which reported the average request made by women was $\$ 19.34$ and the average request made by men was $\$ 21.47$, which shows men asked for marginally more.

Starbucks gift cards were given to the two participants who negotiated for the highest amount (\$25). One man and one woman each asked for $\$ 25$. The woman, age 29 , reported her highest salary as $\$ 125,000$, claiming she performed on par with her coworkers, and was an above average negotiator. The man, age 25 , reported his highest salary as $\$ 43,500$, claiming he performed far better than his coworkers, and was an average negotiator. Comparatively, the second highest amount requested of $\$ 15$ was made by a woman, age 29 , who reported her highest salary as $\$ 47,000$, claimed she performed far better than her coworkers, and was a below average negotiator (see Table of Relevant Survey Questions and Responses).

Table of Relevant Survey Questions and Responses

\begin{tabular}{|c|c|c|c|c|c|c|c|c|}
\hline $\begin{array}{l}\text { Respondent } \\
\text { Number }\end{array}$ & Age & Sex & Race & Salary & $\begin{array}{l}\text { I feel I performed } \\
\text { better than my } \\
\text { coworkers in similar } \\
\text { job positions in terms } \\
\text { of work performance } \\
\text { last year }\end{array}$ & $\begin{array}{l}\text { I feel I am } \\
\text { an above } \\
\text { average } \\
\text { negotiator }\end{array}$ & $\begin{array}{l}\text { Request } \\
\text { Made Code }\end{array}$ & $\begin{array}{l}\text { Amount } \\
\text { Requested }\end{array}$ \\
\hline
\end{tabular}




\begin{tabular}{|c|c|c|c|c|c|c|c|c|c|}
\hline 1 & 29 & Female & White & $\$$ & $47,000.00$ & Strongly Agree & Disagree & 2 & $\$ 15.00$ \\
\hline 2 & 23 & Male & White & $\$$ & $16,640.00$ & Neutral & Agree & 0 & N/A \\
\hline 3 & 22 & Female & White & $\$$ & $55,796.00$ & Agree & Agree & 2 & $\$ 10.00$ \\
\hline 4 & 29 & Male & White & $\$$ & $110,000.00$ & Agree & Neutral & 2 & $\$ 5.00$ \\
\hline 5 & 26 & Female & White & $\$$ & $75,000.00$ & Agree & Agree & 2 & $\$ 5.00$ \\
\hline 6 & 25 & Male & White & $\$$ & $47,000.00$ & Agree & Neutral & 0 & $\begin{array}{l}\text { I don't drink } \\
\text { coffee :) }\end{array}$ \\
\hline 7 & 25 & Female & White & $\$$ & $40,000.00$ & Strongly Agree & Agree & 2 & $\$ 10.00$ \\
\hline 8 & 27 & Male & Asian & $\$$ & $40,000.00$ & Agree & Agree & 0 & N/A \\
\hline 9 & 27 & Male & White & $\$$ & $55,000.00$ & Agree & Neutral & 2 & $\$ 10.00$ \\
\hline 10 & 25 & Male & White & $\$$ & $50,000.00$ & Agree & $\begin{array}{l}\text { Strongly } \\
\text { Agree }\end{array}$ & 1 & $\$ 0.00$ \\
\hline 11 & 24 & Female & Hispanic & $\$$ & $40,000.00$ & Strongly Agree & Agree & 2 & $\$ 5.00$ \\
\hline 12 & 27 & Female & White & $\$$ & $71,400.00$ & Agree & Neutral & 2 & $\$ 10.00$ \\
\hline 13 & 24 & Female & White & $\$$ & $33,000.00$ & Strongly Agree & Neutral & 2 & $\$ 10.00$ \\
\hline 14 & 32 & Female & White & $\$$ & $60,000.00$ & Agree & Neutral & 2 & $\$ 5.00$ \\
\hline 15 & 26 & Male & White & $\$$ & $52,000.00$ & Strongly Agree & Agree & 2 & $\$ 3.00$ \\
\hline 16 & 26 & Female & White & $\$$ & $89,440.00$ & Neutral & Disagree & 2 & $\$ 2.00$ \\
\hline 17 & 37 & Male & White & $\$$ & $55,000.00$ & Strongly Agree & Neutral & 2 & $\$ 5.00$ \\
\hline 18 & 24 & Male & White & $\$$ & $34,060.00$ & Strongly Agree & Neutral & 1 & $\$ 0.00$ \\
\hline 19 & 25 & Male & White & $\$$ & $43,500.00$ & Strongly Agree & Neutral & 2 & $\$ 25.00$ \\
\hline 20 & 29 & Female & White & $\$$ & $125,000.00$ & Neutral & Agree & 2 & $\$ 25.00$ \\
\hline 21 & 26 & Male & White & $\$$ & $62,000.00$ & Agree & Agree & 1 & $\$ 0.00$ \\
\hline 22 & 40 & Male & White & $\$$ & $42,000.00$ & Agree & Neutral & 1 & $\$ 0.00$ \\
\hline 23 & 24 & Male & White & $\$$ & $74,800.00$ & Agree & Neutral & 2 & $\$ 10.00$ \\
\hline 24 & 26 & Male & White & $\$$ & $35,000.00$ & Strongly Agree & Agree & 2 & $\$ 6.75$ \\
\hline 25 & 25 & Male & White & $\$$ & $41,600.00$ & Agree & Disagree & 2 & $\$ 5.00$ \\
\hline
\end{tabular}




\section{Discussion}

\subsection{Heuristics and Negotiation}

Where we had anticipated our survey would merely confirm Greig's (2008) findings, instead, our outcomes strikingly ran contrary to what most researchers have discovered about women and negotiation. First, Greig observed that higher-earning employees tended to ask for a lower or no reward, presumably because their salaries dwarfed the value of the rewards card. Second, in Greig's study, while $90 \%$ of men requested a rewards card, only $76 \%$ of women made a request, although the differences in value between the amounts requested by men versus women was statistically insignificant. In contrast, in our study, $100 \%$ of women requested a rewards card, compared to only $73 \%$ of men, a near-inversion of Greig's findings. More important, women not only requested, on average, twice the value requested by men but also requested two of the three highest card values. The disparity between amount requested and perception of oneself compared to peer group most likely stems from an availability bias.

\subsection{Availability Bias}

While underused as an explanation for disparities in negotiation between the sexes, availability has long played a role in decision-making, when frequent or recent exposure leads individuals to make correlations between the most frequently or recently observed phenomenon and the scenario at hand (Tversky \& Kahneman, 1973). In particular, availability biases play such a muscular role in medical misdiagnoses made by recent graduates of medical school that Tversky and Kahneman's original paper on availability bias sprang from earlier studies of medical misdiagnoses (Chapman \& Chapman, 1967). In addition, medical residents and fellows, continuing their training, continually receive schooling to steer them away from availability biases. As medical studies emphasize rare diseases and conditions, clinicians new to practice tend to diagnose patients with the same rare diseases they most recently studied, rather than the more mundane and routine diagnoses their patients present to them (Redelmeier, 2005). To counter availability biases in recently-trained clinicians, senior or attending clinicians train them to ignore recently-studied rare diseases in favor of the diseases they are statistically most likely to encounter (McDonald, 1996). Availability biases figure so strongly in medicine that evidence-based heuristics direct clinicians' attention deliberately away from them, ultimately making difficult the diagnosis of actual rare conditions and diseases (Sareli, Janssen, Sterman, Saint \& Pyeritz, 2008).

\subsection{How Availability Biases Shaped Survey Responses}

Similarly, in negotiation, availability accounts for the both "sticky floor" and "glass ceiling" that keep women from receiving the lucrative salaries of their male counterparts. Relying on their most recent salary, negotiation, experiences or discussions of either among their social networks, women set targets for first offers lower than those set by men, accounting for lower first offers made by women, as observed by researchers from Babcock and Laschever (2007) through Rosette, Kopelman, and Abbott (2014). In our study, the top requests were both made by participants who felt they were making relatively high salaries. However, the woman's availability bias, linked to her $\$ 125,000$ salary as an intern, being groomed for top management in a multinational Fortune 500 company, made her perceive herself as performing merely on par with her peers, while she ranked herself as an above-average negotiator. Similarly, the second-highest value requested by female respondents was also made by a woman with experience in a multinational Fortune 500 organization, with an availability bias linked less to her own salary-significantly lower than some of the other women in her cohort - than those of the mostly male colleagues around her. Significantly, both women worked in the mostly male-dominated financial services sector, which may have provided them with availability biases canted toward the comparatively lucrative salaries earned by men working alongside them. Since Greig's entire 2008 sample consisted of participants in banking, men and women alike would have probably relied on availability biases of salaries of colleagues of the same sex within their organization, eliminating the cross-sex availability bias we discovered.

\subsection{Framing as a Significant Influence in Negotiation}

Framing effects also played a role in the values requested by study participants. Both men and women, in requesting values, reporting performance, and estimating their skill in negotiation were influenced by their workplace, peers, and age group - in some instances, more markedly by these frames than they were by availability, which seemed to influence only the top-value requests. For example, the man who also requested the top amount as his reward reported a salary only a third of his top-requesting female classmate's but felt he outperformed his colleagues in the workplace but was merely an average negotiator. As a 25 year-old man who had worked only in a small municipal government, with little experience outside his home state, he clearly felt he earned a relatively high salary for his age and work peer group, rating his skill ranking his performance amongst his workplace peer group as superior. Notably, despite the high value he requested as his reward, he ranked his skills as a negotiator as merely average. 


\subsection{Heuristics Guide Judgment in Ambiguous Contexts}

Our participants were also likely guided by heuristics stemming from the contextual ambiguity generated by our survey, which included sham questions to mislead participants about its purpose - a condition that somewhat mimics the lack of cues many negotiators face in making first offers for compensation (Tversky \& Kahneman, 1974; Bowles, Babcock \& McGinn, 2005; Magee, Galinsky \& Gruenfeld, 2007). Contextual ambiguity can cue stereotyping behavior (Wheeler \& Petty, 2001) that glues women firmly to the sticky floor or mid-level bottleneck (Yap \& Conrad, 2009). However, in our study, women seemed to have relied, instead, on representativeness heuristics (Tversky \& Kahneman, 1974), using their salaries to guide their sense of worth and performance relative to their workplace peers, even as their tendency to negotiate higher-value rewards was inversely correlated to their belief in their own abilities as negotiators. Significantly, women tended to make significantly higher salaries than the men in the study before their salaries influenced the amount they requested as a reward for completing the survey (see Table of Relevant Survey Questions and Responses). Deprived of anchors to guide their value requests (Galinsky \& Mussweiler, 2001), women in our survey relied, instead, on availability, framing, and representativeness heuristics in making value requests.

\subsection{Study Limitations}

As behavioral economists have themselves noted, small sample sizes can lead to misleading conjectures as to their representativeness of larger phenomena (Kahneman, 2011). However, many studies of women and negotiation have relied on atypical but convenient samples, including undergraduates enrolled in researchers' courses or in MBA programs (e.g., Galinsky \& Mussweiler, 2001; Kray \& Haselhuhn, 2007; Kray, Galinsky \& Markman, 2009; Rosette, Kopelman \& Abbott, 2014). In addition, our small sample size might have resulted in the findings contradicting those reported in the study on which ours was modeled-Greig's 2008 study. However, Greig inconsistently reports the number of participants. The study first reports that Greig randomly selected 50 men and 50 women from a financial institution to complete her survey, then later reports a total sample size of 319 employees, of whom 305 apparently completed her survey-despite Greig reporting an average response rate of $49 \%$ (Greig 2008). Ultimately, our findings jibe with outcomes in other studies with larger sample sizes that similarly found that situational factors exert more influence over negotiation tactics than participants' sex (Gerhart \& Rynes, 1991).

\subsection{Implications: When Heuristic Biases Become Beneficial}

Researchers consistently equate heuristic biases with quick and dirty thinking that more often than not leads to misleading conclusions, including errors from representativeness (Tversky \& Kahneman, 1974; Tversky \& Kahneman, 1981), leading to stereotyping (Ayres \& Siegelman, 1995; Wheeler \& Petty, 2001) or to susceptibility to manipulation (Wheeler \& Berger, 2007; Morewedge \& Kahneman, 2010; Kahneman, 2011). However, this study provides an example of beneficial effects stemming from heuristics like availability. Moreover, our findings support other studies documenting the benefits from another heuristic, anchoring, which resulted in greater satisfaction with negotiation outcomes (Galinsky \& Mussweiler, 2001; Magee, Galinsky \& Gruenfeld, 2007). For female negotiators who lack access to the higher salaries and perceptions of self-worth of our participants, MBA programs can provide female graduate students with priming exercises prior to negotiation, prompting them to reflect on situations in which they outperformed their peers in either the classroom or in a workplace setting (Magee, Galinsky \& Gruenfeld, 2007).

For women who fail to summon memories of an effective performance, their negotiation skills can even improve through exercises in counterfactual thinking. In what researchers have identified as additive counterfactual thinking (Kray, Galinsky \& Markman, 2009; Kray et al., 2010), individuals identify regrets over failed opportunities to negotiate, gaining competitive advantage in future negotiations (Galinsky, Seiden, Kim \& Medvec, 2002; Galinsky, Leonardelli, Okhuysen \& Mussweiler, 2005). Together, availability, anchoring, priming, and counterfactual thinking can work to encourage women to make higher first offers, become more aggressive negotiators, and enable them to free themselves from the sticky floor, mid-level bottleneck, and glass ceiling alike. Even a simple workshop, short course, or module within a course in negotiation could significantly benefit women in negotiating their next salaries by including exercises using priming, availability, and counterfactual thinking.

\section{References}

Ayres, I., \& Siegelman, P. (1995). Race and gender discrimination in bargaining for a new car. American Economic Review, 85(3), 304-321.

Babcock, L., \& Laschever, S. (2007). Women don't ask: The high cost of avoiding negotiation-and positive strategies for change. New York: Bantam. 
Berger, J., Meredith, M., \& Wheeler, S.C. (2008). Contextual priming: Where people vote affects how they vote. Proceedings of the National Academy of Sciences, 105(26), 8846-8849. http://dx.doi.org/10.1073/pnas.0711988105

Bowles, H.R., Babcock, L., \& McGinn, K.L. (2005). Constraints and triggers: Situational mechanics of gender in negotiation. Journal of Personality and Social Psychology, 89(6), 951-965. http://dx.doi.org/10.1037/0022-3514.89.6.951

Burger, J.M., Messian, N., Patel, S., del Prado, A., \& Anderson, C. (2004). What a coincidence! The effects of incidental similarity on compliance. Personality and Social Psychology Bulletin, 30, 35-43. http://dx.doi.org/10.1177/0146167203258838

Chapman, L.J., \& Chapman, J.P. (1967). Genesis of popular but erroneous psychodiagnostic observations. Journal of Abnormal Psychology, 73, 193-204. http://dx.doi.org/10.1037/h0024670

Galinsky, A.D., Leonardelli, G.J., Okhuysen, G.A., \& Mussweiler, T. (2005). Regulatory focus at the bargaining table: promoting distributive and integrative success. Personality and Social Psychology Bulletin, 31, 1087-1098. http://dx.doi.org/10.1177/0146167205276429

Galinsky, A.D, \& Mussweiler, T. (2001). First offers as anchors: the role of perspective-taking and negotiator focus. Journal of Personality and Social Psychology, 81(4), 657-669. http://dx.doi.org/10.1037/0022-3514.81.4.657

Galinsky, A.D., Seiden, V.L., Kim, P.H., \& Medvec, V.H. (2002). The dissatisfaction of having your first offer accepted: The role of counterfactual thinking in negotiations. Personality and Social Psychology Bulletin, 28, 271-283. http://dx.doi.org/10.1177/0146167202282012

Gerhart, B., \& Rynes, S. (1991). Determinants and consequences of salary negotiations by male and female MBA graduates. Journal of Applied Psychology, 76(2), 256-262. http://dx.doi.org/10.1037/0021-9010.76.2.256

Granovetter, M. (1973). The strength of weak ties. American Journal of Sociology, 78(6), 1360-1380. http://dx.doi.org/10.1086/225469

Granovetter, M. (1983). The strength of weak ties: A network theory revisited. Sociological Theory, 1(1), 201-233. http://dx.doi.org/10.2307/202051

Greig, F. (2008). Propensity to negotiate and career advancement: Evidence from an investment bank that women are on a "slow elevator." Negotiation Journal, 24(4), 495-508. http://dx.doi.org/10.1111/j.1571-9979.2008.00200.x

Haselhuhn, M.P., \& Kray, L.J. (2011). The impact of implicit negotiation beliefs on motivation and cognition in group negotiation. In E. Mannix, J. R. Overbeck \& M. Neale (Eds.), Negotiation and Groups (pp. 137-161). New York: Emerald Group Publishing.

Instone, D., Major, B., \& Bunker, B.B. (1983). Gender, self confidence, and social influence strategies: An organizational simulation. Journal of Personality and Social Psychology, 44(2), 322-334. http://dx.doi.org/10.1037/0022-3514.44.2.322

Kahneman, D. (2011). Thinking, fast and slow. New York: Farrar, Straus and Giroux.

Kee, H.J. (2006). Glass ceiling or sticky floor? Exploring the Australian gender pay gap. Economic Record, 82(259), 408-427. http://dx.doi.org/10.1111/j.1475-4932.2006.00356.x

Kray, L.J., \& Babcock, L. (2006). Gender in negotiations: A motivated social cognitive analysis. In L. L. Thompson (Ed.), Negotiation theory and research (pp. 203-224). New York: Psychology Press.

Kray, L.J., Galinsky, A.D., \& Markman, K.D. (2009). Counterfactual structure and learning from experience in negotiations. Journal of Experimental Social Psychology, 45(4), 979-982. http://dx.doi.org/10.1016/j.jesp.2009.03.008

Kray, L.J., \& Gelfand, M.J. (2009). Relief versus regret: The effect of gender and negotiating norm ambiguity on reactions to having one's first offer accepted. Social Cognition, 27(3), 418-436. http://dx.doi.org/10.1521/soco.2009.27.3.418

Kray, L.J., George, L.G, Liljenquist, K.A., Galinsky, A.D, Tetlock, P.E., \& Roese, N.J. (2010). From what might have been to what must have been: counterfactual thinking creates meaning. Journal of Personality and Social Psychology, 98(1), 106-118. http://dx.doi.org/10.1037/a0017905

Kray, L.J., Kennedy, J.A., \& Van Zant, A.B. (2014). Not competent enough to know the difference? Gender stereotypes about women's ease of being misled predict negotiator deception. Organizational Behavior and Human Decision Processes, 125(2), 61-72. http://dx.doi.org/10.1016/j.obhdp.2014.06.002 
Magee, J.C., Galinsky, A.D., \& Gruenfeld, D.H. (2007). Power, propensity to negotiate, and moving first in competitive interactions. Personality and Social Psychology Bulletin, 33(2), $200-212$. http://dx.doi.org/10.1016/j.obhdp.2014.06.002

Major, B., \& Konar, E. (1984). An investigation of sex differences expectations and their possible causes. Academy of Management Journal, 27, 777-792. http://dx.doi.org/10.2307/255878

Major, B., McFarlin, D.B., \& Gagnon, D. (1984). Overworked and underpaid: On the nature of gender differences in personal entitlement. Journal of Personality and Social Psychology, 47, 1399-1412. http://dx.doi.org/10.1037/0022-3514.47.6.1399

McDonald, C.J. (1996). Medical heuristics: The silent adjudicators of clinical practice. Annals of Internal Medicine, 124, 56-62. http://dx.doi.org/10.7326/0003-4819-124-1_Part_1-199601010-00009

Morewedge, C.K., \& Kahneman, D. (2010). Associative processes in intuitive judgment. Trends in Cognitive Sciences, 14(10), 435-440. http://dx.doi.org/10.1016/j.tics.2010.07.004

Morton, F.S., Zettelmeyer, F., \& Silva-Risso, J. (2003). Consumer information and discrimination: Does the Internet affect the pricing of new cars to women and minorities? Quantitative Marketing and Economics, 1(1), 65-92.

Rainbird, H. (2007). Can training remove the glue from the "sticky floor" of low-paid work for women? Equal Opportunities International, 26(6), 555-572.

Redelmeier D.A. (2005). Cognitive psychology of missed diagnoses. Annals of Internal Medicine, 142, $115-120$. http://dx.doi.org/10.7326/0003-4819-142-2-200501180-00010

Riley, H.C., Babcock, L., \& McGinn, K.L. (2003). Gender as a situational phenomenon in negotiation. Unpublished white paper: Carnegie Mellon University.

Rosette, A.S., Kopelman, S., \& Abbott, J.L. (2014). Good grief! Anxiety sours the economic benefits of first offers. Group Decision and Negotiation, 23(3), 629-647. http://dx.doi.org/10.1007/s10726-013-9348-4

Shambaugh, R. (2007). It's not a glass ceiling, it's a sticky floor: Free yourself from the hidden behaviors sabotaging your career success. New York: McGraw-Hill Professional.

Shih, M., Pittinsky, T. L., \& Ambady, N. (1999). Stereotype susceptibility: Identity salience and shifts in quantitative performance. Psychological Science, 10, 80-83. http://dx.doi.org/10.1111/1467-9280.00111

Solnick, S.J. (2001). Gender differences in the ultimatum game. Economic Inquiry, 39, $189-200$. http://dx.doi.org/10.1093/ei/39.2.189

Steele, C.M., \& Aronson, J. (1995). Stereotype threat and the intellectual test performance of African- Americans. Journal of Personality and Social Psychology, 69(5), 797-811.

Stuhlmacher, A.F., \& Walters, A.E. (1999). Gender differences in negotiation outcome: A meta-analysis. Personnel Psychology, 52(3), 653-677. http://dx.doi.org/10.1111/j.1744-6570.1999.tb00175.x

Tesch, B.J., Wood, H.M, Helwig, A.L., \& Nattinger, A.B. (1995). Promotion of women physicians in academic medicine: Glass ceiling or sticky floor? JAMA: Journal of the American Medical Association, 273(13), 1022-1025.

Trout, J.D. (2005). Paternalism and cognitive bias. Law and Philosophy, 24(4), 393-434. http://dx.doi.org/10.1007/s10982-004-8197-3

Tversky, A., \& Kahneman, D. (1974). Judgment under uncertainty: Heuristics and biases. Science, 185(4157), 1124-1131.

Tversky, A., \& Kahneman, D. (1981). The framing of decisions and the psychology of choice. Science, 211(4481), 453-458.

Wheeler, S.C., \& Berger, J. (2007). When the same prime leads to different effects. Journal of Consumer Research, 34(3), 357-368. http://dx.doi.org/10.1086/518547

Wheeler, S.C., \& Petty, R.E. (2001). The effects of stereotype activation on behavior: a review of possible mechanisms. Psychological Bulletin, 127(6), 797-826. http://dx.doi.org/10.1037/0033-2909.127.6.797

Wong, E.M, Haselhuhn, M.P., \& Kray, L.J. (2012). Improving the future by considering the past: The impact of upward counterfactual reflection and implicit beliefs on negotiation performance. Journal of Experimental Social Psychology, 48(1), 403-406. http://dx.doi.org/10.1016/j.jesp.2011.07.014

Yap, M., \& Konrad, A.M. (2009). Gender and racial differentials in promotions: Is there a sticky floor, a mid-level bottleneck, or a glass ceiling? Relations industrielles/Industrial Relations, 64(4), 593-619. 